\title{
PENGARUH RENDAM KAKI DENGAN AIR HANGAT TERHADAP TINGKAT KECEMASAN PADA IBU HAMIL
}

\author{
Fitria Hikmatul Ulya ${ }^{1}$, Yuniarti Purnaningrum² \\ 1,2Program Studi Sarjana Terapan Kebidanan, \\ Sekolah Tinggi Ilmu Kesehatan Karya Husada Semarang \\ Jl. Kompol R. Soekanto No. 46 Semarang, Kec. Tembalang Kota Semarang \\ Telp: (024) 6724581 \\ E-mail: fitria12hikmatul@gmail.com
}

\begin{abstract}
ABSTRAK
Merendam kaki dengan air hangat dapat mengakibatkan vasodilatasi pembuluh darah yang mengakibatkan aliran darah menjadi lancar sehingga otot dapat berelaksasi. Di Kabupaten Kudus tingkat kecemasan ibu hamil menjelang persalinan sebanyak 44,2\%. Tujuan penelitian ini adalah untuk mengetahui pengaruh rendam kaki dengan air hangat terhadap tingkat kecemasan pada ibu hamil trimester III di wilayah Puskesmas Jati. Jenis penelitian pra eksperimen dengan desain penelitian one group pretest posttest. Populasi penelitian adalah semua ibu hamil trimester III di wilayah Puskesmas Jati bulan Pebruari 2019 dengan sampel 16 orang. Teknik pengambilan sampelnya purposive sampling. Merendam kaki setinggi $10-15 \mathrm{~cm}$ dengan air hangat selama 2030 menit. Rata-rata tingkat kecemasan sebelum sebesar 61,75 (kecemasan berat) sedangkan sesudah sebesar 54,13 (kecemasan ringan sedang). Ada pengaruh rendam kaki dengan air hangat terhadap tingkat kecemasan pada ibu hamil trimester III, $p$ value 0,033 dengan selisih tingkat kecemasan sebesar 7,62. Ibu hamil diharapkan dapat menurunkan tingkat kecemasan yang dialaminya dengan menggunakan rendam kaki air hangat.
\end{abstract}

Kata Kunci: Rendam Kaki, Tingkat Kecemasan; Ibu Hamil Trimester III

\begin{abstract}
Soaking feet with warm water can result in vasodilation in the blood vessels that caused the bloodstream to run smoothly so the muscle can be relaxed. In Kudus Regency, the rate of the anxiety of pregnant mothers approaching the birth date is $44,2 \%$. The purpose of this study was to determine the effect of soaking feet with warm water on the level of anxiety in third trimester pregnant women in the Puskesmas Jati region. The type of research is using the pra experiment with one group pretest-posttest research design. The sample of this research is 16 pregnant mothers in the third semester around the Puskesmas Jati region in February of 2019. The technique to gather the sample is using purposive sampling. Soaking feet with boiled water for $10 \mathrm{~cm}-15 \mathrm{~cm}$ deep for $20-30$ minutes. The average rate of anxiety before is about 61,75 (hard anxiety) while after the treatment is about 54,13 (medium anxiety). The effect of feet soaking with warm water to the third-semester pregnant mother is p-value 0,033 with a different rate of 7,62. The pregnant mother hopefully can reduce the anxiety level by soaking their feet in warm water.
\end{abstract}

Keywords: Feel Soaking, Anxiety Level, Third Semester of Pregnant Mother 


\section{PENDAHULUAN}

Risiko kehamilan cukup membuat resah ibu hamil, meskipun diketahui dalam proses kehamilan akan terjadi perubahanperubahan fisik maupun psikologis. Perubahan fisik tersebut berupa peningkatan hormon yang juga dapat mempengaruhi suasana hati seseorang. Perubahan psikologis sendiri seperti ketakutan, kekhawatiran, dan kecemasan (Padila, 2015) Kecemasan merupakan keadaan emosi tanpa objek tertentu, bingung, khawatir pada sesuatu yang terjadi dengan penyebab yang tidak pasti dan perasaan tidak menentu dan tidak berdaya.

Angka kejadian kecemasan pada ibu hamil di Indonesia mencapai 373.000. Sebanyak 107.000 atau 28,7\% diantaranya kecemasan terjadi pada ibu hamil menjelang proses persalinan (Dinkes RI, 2009). Di Jawa Tengah angka kejadian kecemasan sebanyak 38,2 \% (Dinkes Prov. Jateng, 2015). Sedangkan penelitian yang dilakukan di Kabupaten Kudus didapatkan hasil sebanyak $44,2 \%$ ibu hamil mengalami kecemasan menjelang persalinan (Dinkes Kabupaten Kudus, 2015).

Usia, paritas ibu hamil, tingkat pendidikan dan pekerjaan menjadi faktor penyebab munculnya tingkat kecemasan pada ibu hamil. Kecemasan pada ibu hamil dapat timbul khususnya pada trimester ketiga kehamilan hingga saat persalinan, dimana pada periode ini ibu hamil merasa cemas terhadap berbagai hal seperti normal atau tidak normal bayinya lahir, nyeri yang akan dirasakan, dan sebagainya (Handayani, 2015). Tingkat kecemasan dikelompokkan menjadi empat 4 yaitu kecemasan ringan, kecemasan sedang, kecemasan berat dan panic (Usman, 2016).

Kecemasan dapat dikurangi dengan beberapa terapi penurun kecemasan yaitu terapi farmakologi dan non-farmakologi. Salah satu terapi non farmakologi yaitu rendam kaki dengan air hangat. Rendam kaki air hangat merupakan kondisi kaki yang kontak langsung dengan air hangat. Rendam kaki air hangat dilakukan pada suhu $38^{\circ}$ $39^{\circ} \mathrm{C}$. Menurut penelitian yang dilakukan oleh Akmal (2010) menjelaskan tentang prinsip dasar merendam kaki dengan air hangat dapat mengakibatkan vasodilatasi pembuluh darah yang mengakibatkan aliran darah menjadi lancar sehingga otot dapat berelaksasi. Banyak kegunaan rendam kaki dengan air hangat bagi kesehatan.

Hasil studi pendahuluan di Puskesmas Jati, dari 10 ibu hamil trimester III yang memeriksakan kandungan ke Puskesmas Jati, 6 diantaranya mengalami kecemasan. Hal ini dikarenakan ibu baru pertama kali hamil, dan memikirkan tentang kapan persalinan akan terjadi, bagaimana proses persalinan yang akan dilalui, kemungkinan persalinan dengan operasi, biaya persalinan. Untuk mengatasi kecemasan yang dialami, ibu berusaha untuk mencari informasi dari keluarga di rumah, teman, buku atau majalah, dan internet serta berusaha 
melakukan terapi sendiri dengan menarik napas panjang beberapa kali.

Berdasarkan hal tersebut maka tujuan penelitian adalah pengaruh rendam kaki dengan air hangat terhadap tingkat kecemasan pada ibu hamil trimester III di wilayah Puskesmas Jati.

\section{METODE}

Jenis penelitian yang digunakan adalah pra eksperimen. Pra eksperimen adalah rancangan penelitian eksperimen yang hanya mempergunakan kelompok eksperimen saja, tanpa kelompok kontrol (pembanding) (Notoatmodjo, 2010). Desain penelitian yang digunakan dalam penelitian ini adalah rancangan One Group Pretest Posttest. Rancangan ini sudah dilakukan observasi pertama (pretest) setelah diberikan perlakuan dilakukan pengukuran (posttest) lagi untuk mengetahui akibat dari perlakuan itu, sehingga besarnya efek dari eksperimen dapat diketahui dengan pasti (Notoatmodjo, 2010).

Sampel untuk penelitian ini adalah 16 orang ibu hamil Trimester III di wilayah Puskesmas Jati Kudus pada bulan April 2019 dalam kurun waktu satu bulan. Penelitian ini menggunakan instrumen berupa Standar Operasional Prosedur (SOP) rendam kaki dengan air hangat dan kuesioner tingkat kecemasan Zung Self Rating Anxiety Scale. Indikator penilaian yang dipakai untuk mengetahui tingkat kecemasan adalah normal $\leq 45$, kecemasan ringan sedang $46-$ 59 , kecemasan berat $60-74$, kecemasan berat sekali (panik) > 75. Variabel independen dalam penelitian ini adalah rendam kaki dengan air hangat, sedangkan variabel dependennya adalah tingkat kecemasan. Data penelitian diuji menggunakan Paired T-Test dengan uji normalitas data menggunakan Shapiro-Wilk karena sampel 16 orang.

\section{HASIL}

Tingkat Kecemasan Sebelum dan Sesudah Rendam Kaki dengan Air Hangat Tabel 1. Distribusi Frekuensi Responden Berdasarkan Tingkat Kecemasan Sebelum dan Sesudah Rendam Kaki dengan Air Hangat

\begin{tabular}{|c|c|c|c|}
\hline Kelompok & $\begin{array}{l}\text { Nilai } \\
\text { Mean }\end{array}$ & SD & Max \\
\hline Sebelum & 61,75 & $\pm 10,655$ & $\begin{array}{l}42- \\
78\end{array}$ \\
\hline Sesudah & 54,13 & $\pm 9,674$ & $\begin{array}{l}41- \\
69\end{array}$ \\
\hline
\end{tabular}

Berdasarkan tabel 1, kelompok sebelum dilakukan rendam kaki dengan air hangat nilai mean 61,75; standar deviasi $+10,655$; nilai minimal 42 dan nilai maksimalnya adalah 78 . Sedangkan pada kelompok sesudah diberi perlakuan rendam kaki dengan air hangat nilai mean 54,13; standar deviasi $+9,674$; nilai minimal 41 dan nilai maksimalnya adalah 69 .

\section{Pengaruh Rendam Kaki dengan Air} Hangat terhadap Tingkat Kecemasan

Tabel 2. Pengaruh Rendam Kaki dengan Air Hangat terhadap Tingkat Kecemasan 


\begin{tabular}{lccc}
\hline Kelompok & $\begin{array}{c}\text { Nilai } \\
\text { Mean }\end{array}$ & SD & $\begin{array}{c}\boldsymbol{p} \text { - } \\
\text { value }\end{array}$ \\
\hline Sebelum & 61,75 & $\pm 10,655$ & 0,033 \\
Sesudah & 54,13 & $\pm 9,674$ & \\
\hline Selisih $\Delta$ & 7,62 & $+0,981$ & \\
\hline
\end{tabular}

Berdasarkan tabel 2, hasil uji menggunakan Paired T-Test nilai mean sebelum sebesar 61,75 dan nilai mean sesudah sebesar 54,13 dengan selisih tingkat kecemasan sebesar 7,62; sedangkan nilai $p$-value $0,033 \leq 0,05$, artinya ada pengaruh rendam kaki dengan air hangat terhadap tingkat kecemasan pada ibu hamil trimester III di wilayah Puskesmas Jati.

\section{PEMBAHASAN}

Berdasarkan hasil penelitian yang telah diuraikan di atas, peneliti akan melakukan pembahasan lebih lanjut yaitu menginterprestasikan data hasil penelitian sambil membandingkan dengan teori-teori yang ada.

Berdasarkan hasil penelitian dapat diketahui bahwa sebelum dilakukan rendam kaki dengan air hangat didapatkan rata-rata tingkat kecemasan adalah 61,75 termasuk tingkat kecemasan berat; standar deviasi \pm 10,655 ; nilai tengah 63,00 ; nilai minimal 42 dan nilai maksimalnya adalah 78 .

Hasil analisis peneliti tentang tingkat kecemasan pada ibu hamil dapat timbul khususnya pada trimester ketiga kehamilan hingga saat persalinan, dimana pada periode ini ibu hamil merasa cemas terhadap berbagai hal seperti normal atau tidak normal bayinya lahir, nyeri yang akan dirasakan, kondisi ibu hamil, proses persalinan, dan lainlain.

Meskipun risiko kehamilan cukup membuat resah ibu hamil, tetapi dalam proses kehamilan pasti akan terjadi perubahan-perubahan fisik maupun psikologis. Perubahan fisik tersebut berupa peningkatan hormon yang juga dapat mempengaruhi suasana hati seseorang. Perubahan psikologis sendiri seperti ketakutan, kekhawatiran, dan kecemasan (Dinkes Kabupaten Kudus, 2015).

Kecemasan merupakan emosi yang tidak menyenangkan, yang ditandai dengan kekhawatiran, keprihatinan dan rasa takut yang kadang kita alami dalam tingkat yang berbeda (Maimunah, 2011).

Setiap tingkatan kecemasan memiliki lahan persepsi yang berbeda pada setiap individu tergantung pada kemampuan individu dalam menerima informasi dan pengetahuan mengenai kondisi yang ada dalam dirinya maupun lingkungannya (Usman, 2016).

Informasi dari tenaga kesehaan penting bagi ibu hamil karena informasi yang diperoleh dapat mempengaruhi tingkat kecemasan ibu hamil dalam menghadapi persalinan. Kelengkapan informasi yang diperoleh mengenai keadaan lebih lanjut mengenai kehamilannya, termasuk adanya penyakit penyerta dalam kehamilan, membuat ibu hamil lebih siap dengan semua kemungkinan yang akan terjadi saat persalinan dan ibu tidak terbebani dengan perasaan takut dan cemas. Selain informasi 
dari tenaga kesehatan, dukungan suami juga merupakan faktor yang penting bagi ibu hamil. Dukungan suami dapat mengurangi kecemasan sehingga ibu hamil trimester ketiga dapat merasa tenang dan memiliki mental yang kuat dalam menghadapi persalinan (Shodiqoh, 2014).

Berdasarkan hasil penelitian dapat diketahui bahwa sesudah dilakukan rendam kaki dengan air hangat didapatkan rata-rata tingkat kecemasan adalah 54,13 termasuk tingkat kecemasan ringan sedang; standar deviasi $\pm 9,674$; nilai tengah 56,50 ; nilai minimal 41 dan nilai maksimalnya adalah 69 .

Rendam kaki air hangat adalah penggunaan air untuk menyembuhkan dan meringankan berbagai keluhan. Rendam kaki adalah terapi dengan cara merendam kaki hingga batas 10-15 cm di atas mata kaki menggunakan air hangat pada suhu $35^{\circ}$ $38^{\circ} \mathrm{C}$ selama $20-30$ menit (Hambing, 2010).

Cara kerja rendam kaki dengan air hangat ketika tubuh sedang stress atau sakit, perubahan yang terjadi mengakibatkan denyut nadi dan tekanan darah meningkat. Telah diamati bahwa rendam kaki dengan air hangat mampu meringankan kondisi tersebut dengan mengurangi tingkat stress.

Rendam kaki dengan air hangat mempunyai kemampuan yang sudah diakui sejak dahulu untuk membuat tubuh rileks, menyingkirkan rasa pegal-pegal dan kaku di otot dan mengantar agar tidur bisa nyenyak.

Berdasarkan penelitian yang dilakukan oleh Akmal (2010) menjelaskan tentang prinsip dasar merendam kaki dengan air hangat dapat mengakibatkan vasodilatasi pembuluh darah yang mengakibatkan aliran darah menjadi lancar sehingga otot dapat berelaksasi. Banyak kegunaan rendam kaki dengan air hangat bagi kesehatan. Pemberian essensial oil yang dicampur dengan air hangat mempunyai manfaat untuk memberikan rileksasi tubuh.

Setelah diberikan terapi rendam kaki dengan air hangat responden merasa segar, rileks, ketegangan menurun. Perasaan waswas yang selama ini dirasakan oleh responden berkurang. Hal ini dikarenakan efek dari terapi yang mampu mengurangi tingkat kecemasan dengan cara merangsang produksi endorphin.

Ada pengaruh rendam kaki dengan air hangat terhadap tingkat kecemasan dengan $p$ value 0,033 dan selisih tingkat kecemasan sebelum dan sesudah sebesar 7,62.

Hasil penelitian menunjukkan merendam kaki dengan air hangat mampu meningkatkan sirkulasi darah, mengurangi edema, meningkatkan relaksasi otot, menyehatkan jantung, mengendorkan otototot, menghilangkan stress dan kecemasan, meringankan rasa sakit, meningkatkan permeabilitas kapiler, memberikan kehangatan pada tubuh, daun mint sendiri sangat efektif untuk mengendalikan kecemasan karena senyawa tersebut dapat merangsang system saraf sehingga dapat memberikan efek anti kecemasan.

Rendam kaki air hangat mempunyai dampak fisiologis bagi tubuh, pertama dampaknya air hangat membuat sirkulasi 
darah menjadi lancar. Pada pengobatan tradisional Cina kaki merupakan jantung kedua pada manusia dikarenakan ada banyak titik akupuntur di telapak kaki terdiri enam meridian yaitu hati, kantung empedu di kandung kemih, jantung, ginjal, limfa dan perut sehingga mewakili (berhubungan) dengan seluruh bagian tubuh terutama organ vital jantung berada pada terdapat telapak kaki kiri sehingga bisa memperbaiki sirkulasi darah ke jantung. Merendam kaki dengan air panas bisa memanaskan seluruh tubuh, meningkatkan sirkulasi darah kebagian atas dan menekan sirkulasi (Hambing, 2010).

Dalam pemaparan Dinas Kesehatan Indonesia (2014) air hangat membuat kita merasa santai, meringankan sakit dan tegang pada otot dan memperlancar peredaran darah. Maka dari itu, berendam air hangat bisa membantu menghilangkan stres dan membuat kita tidur lebih mudah. Suhu air hangat yang dipakai berkisar $35^{\circ} \mathrm{C}$.

Penelitian yang sudah dilakukan Khotimah (2012) bahwa terapi rendam kaki air hangat pada kaki memperbaiki mikrosirkulasi pembuluh darah dan vasodilatasi sehingga meningkatkan kuantitas tidur. Rendam kaki air hangat pada kaki efektif digunakan untuk meningkatkan kuantitas tidur pada lansia yang mengalami gangguan tidur.

Secara alamiah terapi rendam kaki air hangat mempunyai dampak fisiologis bagi tubuh. Pertama berdampak pada pembuluh darah dimana hangatnya air membuat sirkulasi darah menjadi lancar, yang kedua adalah faktor pembebanan didalam air yang menguntungkan otot-otot ligament yang mempengaruhi sendi tubuh (Devsaran, 2014).

Terapi rendam kaki air hangat merupakan salah satu terapi yang memberikan efek teraupetik karena air hangat mempunyai dampak fisiologis bagi tubuh. Dampak tersebut dapat mempengaruhi oksigenasi jaringan, sehingga dapat mencegah kekakuan otot, menghilangkan rasa nyeri, menenangkan jiwa dan merilekskan tubuh (Kusumastuti, 2011).

Penanganan kecemasan hendaknya dilakukan sedini mungkin selama kehamilan dalam upaya menghadapi persalinan yang akan datang. Kecemasan yang timbul harus diketahui dengan betul faktor apa yang membuat ibu cemas, hal dasar inilah yang menjadi acuan dalam penanganan yang tepat dalam menangani kecemasan yang timbul. Jika penanganan kurang tepat akan membuat ibu mudah tersinggung, lesu atau lemas, mudah menangis, gelisah, susah tidur, depresi, mempengaruhi persepsi dan pembelajaran. Kecemasan cenderung menimbulkan kebingungan dan distorsi persepsi waktu dan ruang tetapi juga orang dan arti peristiwa. Distorsi ini dapat menggangu proses pembelajaran dengan menurunkan konsentrasi, mengurangi daya ingat, dan menggangu kemampuan menghubungkan satu hal dengan hal yang lain yaitu membuat asosiasi (Sadock, 2015). 
Peneliti beranggapan pengetahuan ibu akan pentingnya tentang penanganan tingkat kecemasan pada akhirnya akan meningkatkan pemahaman, kemampuan dan kemauan untuk melaksanakan penanganan kecemasan dengan rendam kaki dengan air hangat secara benar karena dengan melakukan rendam kaki dengan air hangat maka akan mengurangi tingkat kecemasan yang timbul yang pada akhirnya akan mempermudah ibu trimester III dalam menghadapi persalinan yang akan datang.

Dibutuhkan juga kesediaan untuk mengetahui faktor pemicu timbulnya kecemasan yang dialami secara dini, sehingga ibu dapat mengurangi tingkat kecemasan yang timbul dengan rendam kaki dengan air hangat untuk mengurangi tingkat kecemasan yang ditimbulkanya dan dapat merangsang sistem saraf sehingga dapat memberikan efek anti kecemasan (Sastrohamidjojo, 2010).

\section{KESIMPULAN}

Hasil penelitian didapatkan kesimpulan ada pengaruh rendam kaki dengan air hangat terhadap tingkat kecemasan pada ibu hamil trimester III, $p$ value 0,033 dengan selisih tingkat kecemasan sebesar 7,62. Rata-rata tingkat kecemasan sebelum rendam kaki dengan air hangat sebesar 61,75 (kecemasan berat) sedangkan rata-rata tingkat kecemasan sesudah rendam kaki dengan air hangat sebesar 54,13 (kecemasan ringan sedang).

Penelitian rendam kaki air hangat ini semoga memberikan manfaat untuk berbagai kalangan. Diharapkan ibu hamil dapat menurunkan tingkat kecemasan yang dialaminya dengan menggunakan rendam kaki air hangat. Pengembangan ilmu pengetahuan di bidang penelitian dan pendidikan diharapkan mampu memanfaatkan hasil penelitian ini untuk memperkaya ilmu dan mengembangkan penelitian selanjutnya.

\section{DAFTAR PUSTAKA}

Devsaran. 2014. Rendam Kaki Air Hangat Mempercepatkan Peredaran Darah. Diakses 5 Desember 2018 pada pkl. 18.30 wib

Dinkes Kabupaten Kudus. 2015. Profil Kesehatan Daerah Kabupaten Kudus Tahun 2015. Kudus: Dinkes Kudus.

Dinkes Prov. Jateng. 2015. Profil Kesehatan Provinsi Jawa Tengah Tahun 2015. Semarang.

Dinkes RI. 2009. Audit Maternal Perinatal. Jakarta: Depkes RI.

Hambing, KW. 2010. Keefektifan Rendam Kaki Menggunakan Air Hangat. Diakses 3 Desember 2018 pada pkl. 20.00 wib

Handayani, Reska. 2015. Faktor-faktor yang Berhubungan dengan Tingkat Kecemasan Menjelang Persalinan pada Ibu Primigravida Trimester III di Wilayah Kerja Puskesmas Lubuk Buaya Padang Tahun 2012. Ners Jurnal Keperawatan. Vol 11, No. 1 Maret 2015, ISSN: 1907-686X.

Khotimah (2012). Pengaruh Rendaman Air Hangat pada Kaki dalam Meningkatkan Kuantitas Tidur Lansia. Jombang: UPTDU Journal Nursing Studies

Kusumastuti. 2011. Pengaruh Rendam Air Hangat Pada Kaki Dalam 
Meningkatkan Kuantitas Tidur Lansia.

Tesis. Jombang: Universitas

Pesantren Tinggi Darul Ulum Jombang. Jombang

Maimunah, S. 2011. Kecemasan Ibu Hamil Menjelang Persalinan Pertama. Jurnal Humanity. 5 (1): 61-67.

Notoatmodjo, S. $2010 . \quad$ Metodologi Penelitian Kesehatan. Jakarta: Rineka Cipta.

Padila. 2015. Keperawatan Maternitas. Yogyakarta: Nuha Medika.

Sadock BJ, etc. 2015. Kaplan Sadock's Synopsis of Psychiatry: Behavioral Sciences/Clinical Psychiatry. Edisi 11. Wolters Kluwer Health. New YorkUSA.

Sastrohamidjojo, H. 2010. Kimia Minyak Atsiri. Yogyakarta: Universitas Gajah Mada

Shodiqoh ER, dkk, 2014. Perbedaan Tingkat Kecemasan Dalam Menghadapi Persalinan Antara Primigravida dan Multigravida. Jurnal Berkala Epidemiologi. 2 (1): 141-150

Usman FR, Kundre RM, Onibala F. 2016. Perbedaan Tingkat Kecemasan Ibu Hamil Menghadapi Persalinan Dengan Kepatuhan Antenatal Care (ANC) Di Puskesmas Bahu Kota Manado. Ejournal Keperawatan (eKp). 4 (1): 1-7. 